\title{
手術スケッチノススメ \\ 一前交通脳動脈瘤手術所見の描き方一
}

田中 俊英

東京慈恵会医科大学附属柏病院脳神経外科

\section{はじめに}

2015 年から筆者の所属施設でも電子カルテが導入さ れ，デジタル化偏重の波が押し寄せている.

手術記録を残す重要性については，古くから強調され ている ${ }^{4)}$. 画質が向上し, デジタルカメラで撮影した写 真や顕微鏡下手術の動画編集が容易になり，手術録に揭 載する術中所見に関する記載をこれらデジタル機器で編 集した後にスキャン画像で済ませる傾向がみられる。そ れに伴い術中所見を自分の手でスケッチする意義につい て強調されることは少なくなっているょうに思う。よい
手術イラストを描くためには，術中所見を詳細に観察 し，外科解剖を熟知する必要があり，かつおのおのの手 術のポイントを把握しておく必要がある。

本稿では，筆者の 20 年間にわたる手術スケッチの経 験を踏まえ，自分で手術イラストを描くポイントについ て紹介したい。

\section{手術イラストによる教育法のエッセンス}

手術イラストのメリットは，(1)手術に必要な解剖とオ リエンテーションの習得に役立つ，(2)1 枚の絵に手術の
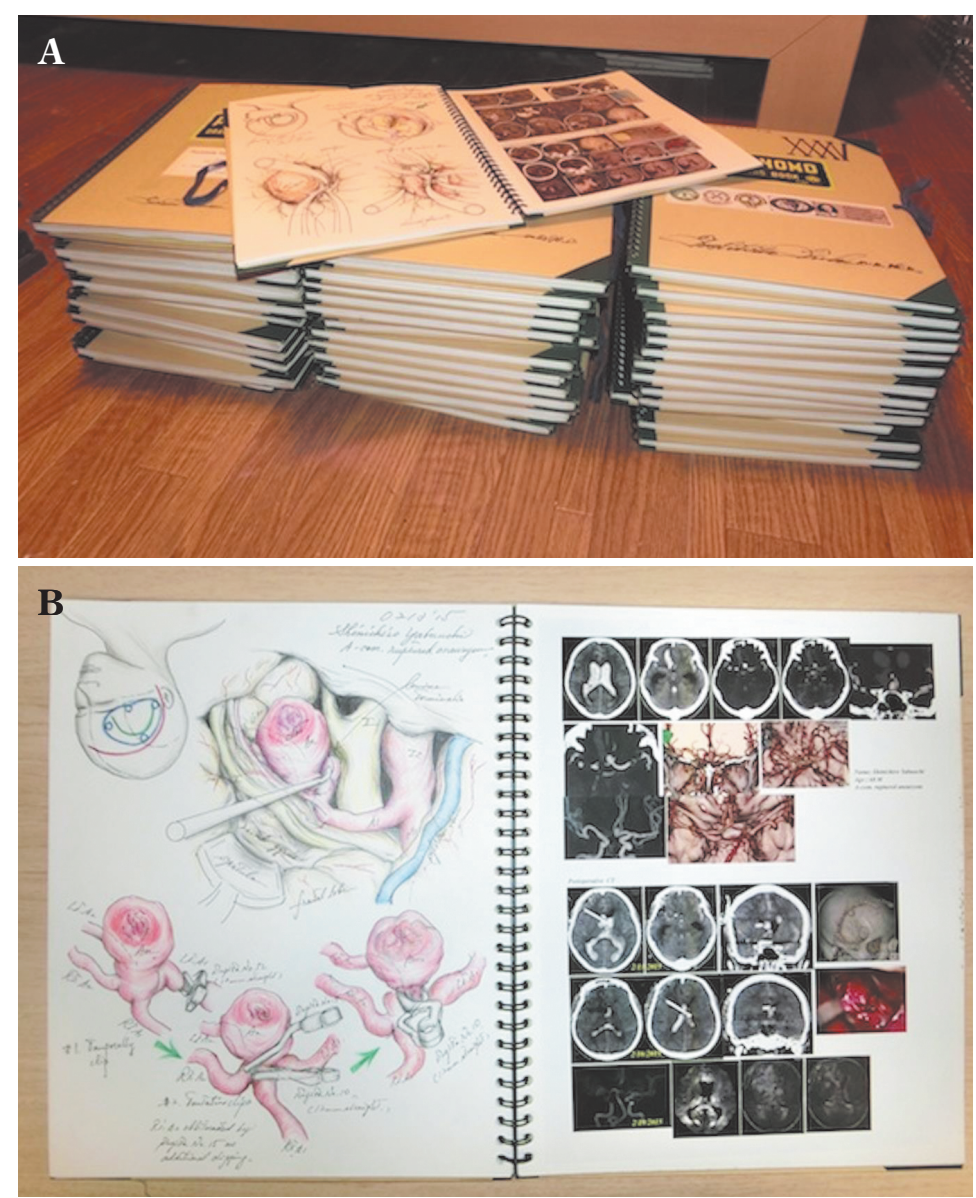

Fig. 1 

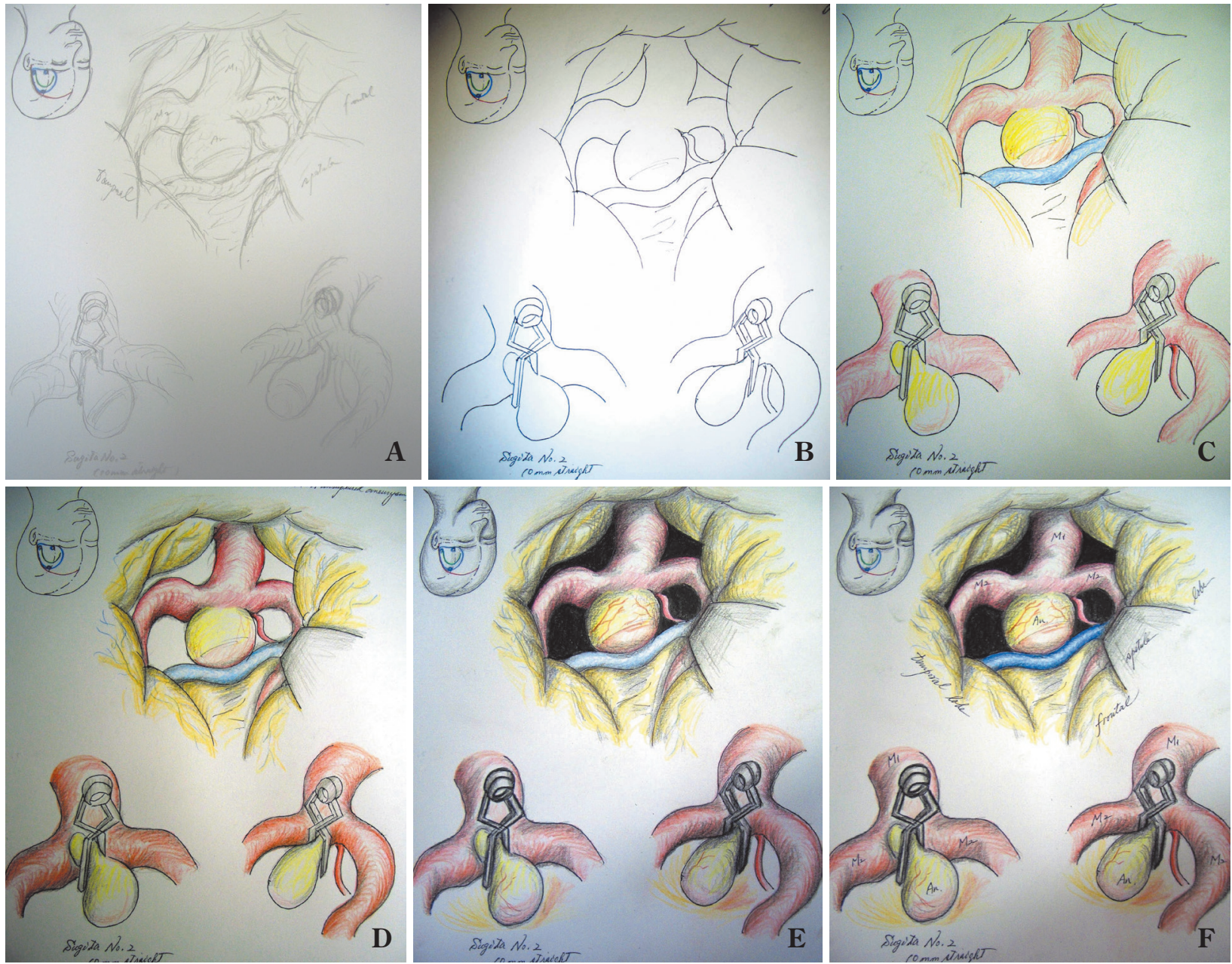

Fig. 2

エッセンスを描き込むことにより，術中所見を鳥瞰的に 観察・思考する能力を養成できる，(3)お打のの手術の ポイントを容易に理解できるようになる，(4)手術戦略の 検討と反省に役立つ，(5)後日同様の手術に打ける留意点 を確認できる，などが挙げられる。また手術記録の記載 は，時間が経過してからでは意味がなく，できるだけ記 憶が鮮明なうちに済ませておくことも大切である。

手術イラストを描く方法として，慣れないうちはデジ タルカメラで撮影した写真やビデオの静止画と照らし合 わせながら描く。慣れてきたら，これらを参照しなくて も描けるように手術シーンを詳細に記憶することが重要 である.

以上の作業は長期継続することが重要であり, 次世代 の術者育成にも役立つと考える。

\section{手術イラストの描き方の工夫と私のこだわり}

すでに他書で述べたが899)，スケッチを行うにあたり 手術と同様，道具にこだわることも大切である。画材と してスケッチブック，色鉛筆，ボールペン，修正液，消 しゴム，雲型定規など各種定規が基本である。

スケッチブックは見開きとし，左側に術中スケッチ， 右側には術前・術後のハイライト画像を貼り付けている

(Fig. 1B).

\section{1 私のこだわり}

1）手術全体を鳥瞰的に振り返る（「メリハリ，脱力」 が重要である).

2) 各手術のハイライトシーンを意識して厳選する(手 術しながらイラストとして描く場面を決める).

3）描くシーンの全体像を最初に決める.

4）どんなに複雑な行程の手術でもスケッチブック“1 

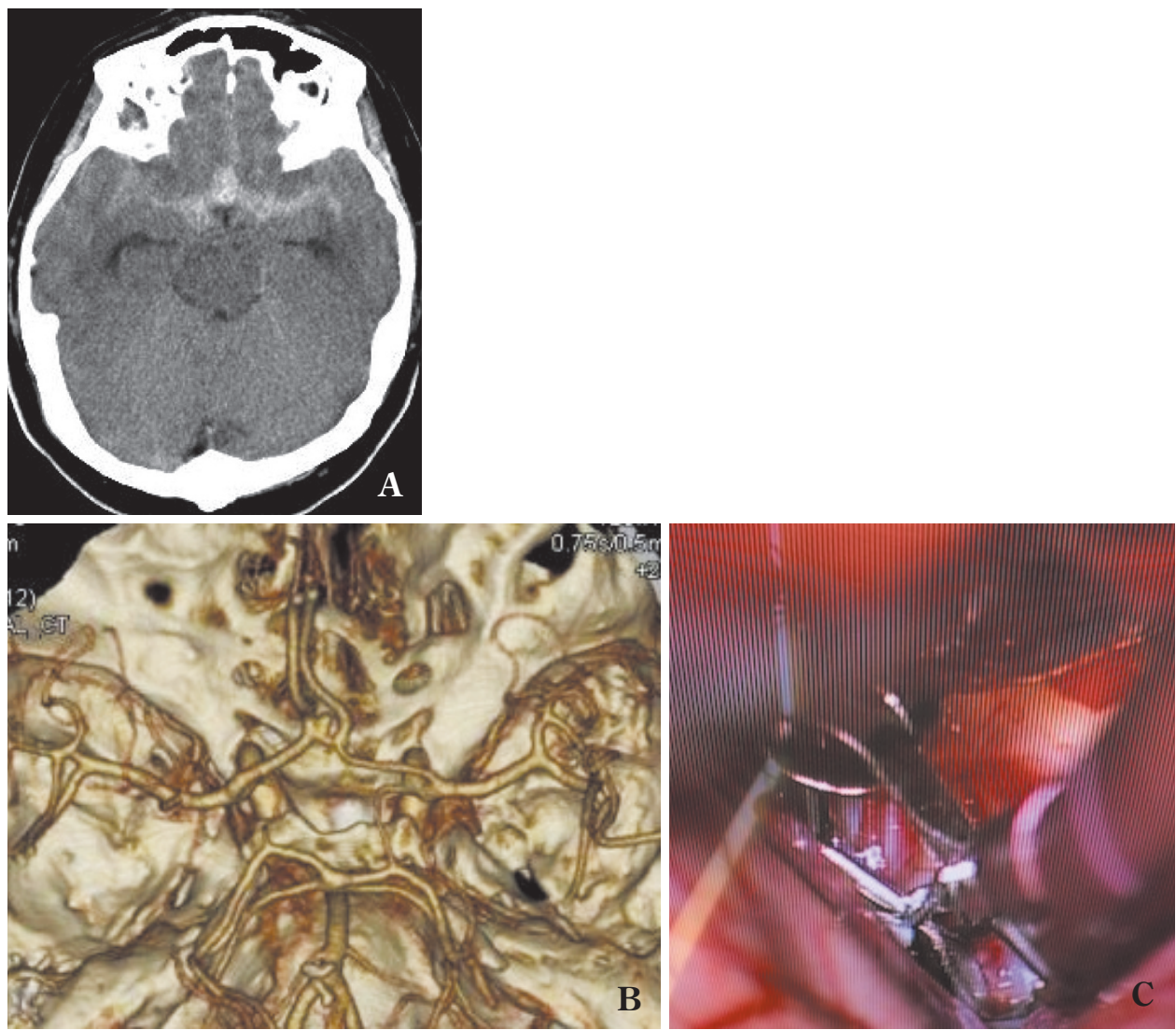

Fig. 3

ページ”に描き切る努力をする，場合によっては，異な る手術場面を同じ画面に描くこともある。“時間と空間 を超越する”記録が残せることも手術イラストのメリッ トの 1 つと考えている.

5）周囲の構造物（骨空, 硬膜切開, 脳溝など）は基本 的にラフに。必要に応じて細かく描く。

6）手術操作で強調したいものを細かく描く。

\section{実際の手術イラスト}

スケッチの手順を以下に述べる（Fig. 2).

(1)鉛筆で下書きをする (Fig. 2A).

(2)ボールペン（黒）で輪郭をなぞる（Fig. 2B）.

(3)色鉛筆で着色する際には，最初は薄い色から塗る. その後重㱛塗りをして立体感を表現する（Fig. 2C）。

(5)影をつけ，深部は黒塗りにするとさらに立体的にな る（Fig. 2D，E）。動脈瘤の壁の硬さを黄色で着色するこ とにより表現する。クリップブレードで parent artery を 閉塞させていないことを示すためにクリッピング終了時 の術中所見を 2 方向から描写した。
6最後に解剖学的構造物の名称を記入して完成である (Fig. 2F).

\section{症 例}

A1-2 complex が右側に開いている上向きの前交通破 裂動脈瘤に対して，クリッピング術を右 pterional approach で行った症例を提示する（Fig. 3)。手術イラス トは sylvian fissure の開放（Fig. 4A）, parent artery の確 保（Fig. 4B）, neck近傍を剝離し，動脈瘤を露出させた 場面（Fig. 4C）までの一連の過程を 1 枚にパノラマ様に 描くことに留意する。実際術中は顕微鏡手術下で強拡大 になると視野は狭くなる（Fig. 3C，Fig. 4A-C)。しかし 手術全体の流水や留意すべき解剖学的構造物を理解する には, Fig. 4Dのごとく手術イラストは多少誇張してでも 鳥瞰的に描くことが大切である。

クリップの挿入方向を surgeon's view で描く(Fig. 4E, $\mathbf{F})$ ．筆者の流儀として，上向きの前交通動脈瘤に対する クリップは，左側からのアプローチであれば時計回り， 右側からのアプローチであれば反時計回りに術者が動き 

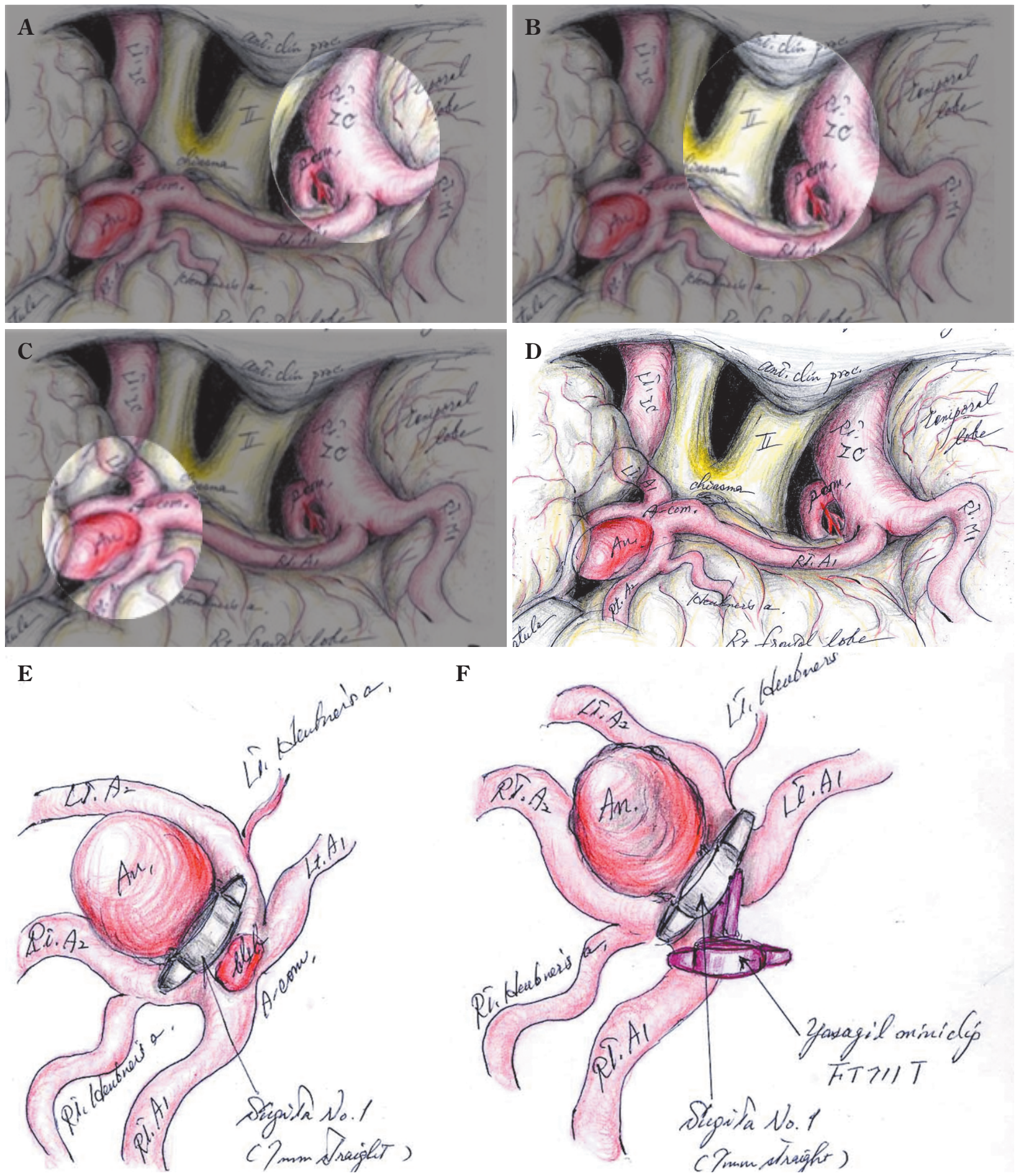

Fig. 4

ながら前頭蓋底からクリップを挿入するようにしてい る。クリップを 2 個以上使用した場合は，クリップを apply するごとにそのシーンを描く.

\section{考 察}

すでに手術イラスト書は先人が出版しており ${ }^{5) ~ 7) ， す ~}$ ばらしい数々のスケッチを目にするが，具体的なイラス トを描く方法やコッは記載されていない。筆者は, 1993 
年の日本脳神経外科学会総会で行われた杉田虔一郎先生 と馬場元毅先生による「手術イラストの描き方」の講演 に啓蒙され, 杉田虔一郎先生の手術アトラス ${ }^{7)}$ と馬場元 毅先生のイラストの描き方の論文や教則本 ${ }^{12) 4}$ から多く を学んだ。通常一人の脳神経外科医が経験できる手術症 例は限りがある。そのため 1 つの手術から多くを学ぶ姿 勢が大切であり, 手術手技の修得には微小解剖の知識に 加え，手術スケッチは欠かせないと考える．動画のス キャン画像の切り貼りは簡便ではあるが，やはり自らの 手で描くことはトレーニング法として強く推奨する。手 術イラストを描くことは, 解剖学的オリエンテーション の習得や術中動画では捉えきれない背後の重要構造物を 意識することなど，経験の浅い若手術者を教育するうえ できわめて有用である。

ただし，手術イラストのピットフォールとして，(1)術 者の主観が入る, (2)肉体的, 精神的要因によりバイアス がかかる, (3)長時間手術後, 多忙時, 時間外急患の手術 後には負担が大きくなり，イラストが雑になる可能性が あることにも留意する必要がある。

スケッチを描くために手術を詳細に振り返ることは術 野を鳥瞰的に観察する修練にもなりうる．1つ1つの小 さな積み重就大きな飛躍につながると信じて，手術久 ケッチは継続することが大切であり, 次世代術者への技 術の継承の一手段としても有用と考える.
著者は日本脳神経外科学会へのCOI 自己申告の登録を完了 しています。本論文に関して, 開示すべきCOIはありません.

本稿の要旨は，2015 年 6 月の関東脳神経外科懇話会（東 京, 大手町) および 2016 年 10 月日本脳神経外科学会総会 (札 幌）で発表した。

\section{文 献}

1）馬場元毅：医学論文におけるメディカルイラストレー ションの意義 [1]. Physic J Feb, 52-55，1993.

2）馬場元毅：医学論文におけるメディカルイラストレー ションの意義 [2]. Physic J Feb, 56-59, 1993.

3）馬場元毅：手術イラストを描くことの意味。脳外誌 25: 435-437, 2016.

4）馬場元毅：Dr. BABA の手術イラストレーション講座一 完成度の高い手術イラストの描き方. 東京, 三輪書店, 2017.

5）菊池晴彦編: 脳神経マイクロサージャリー。東京, 医学 書院, 1988.

6) Lawton MT: Anterior communicating aneurysm. in Lawton MT (ed) : Seven aneurysms. Tenets and techniques for clipping. New York, Thieme, 2010, pp.94-120.

7) Sugita K: Microneurosurgical Atlas. Berlin, SpringerVerlag, 1985.

8）田中俊英：シリーズわたしの手術記載。小児小脳腫瘍. 森田明夫編：新 NS NOW 8 脳神経外科手術のコンパ ス一術中機能・画像情報モニタリングマニュアル．東京, メジカルビュー社, 2016, pp.208-211.

9）田中俊英：シリーズわたしの手術記載。若年性脳動脈奇 形 (左前頭葉)。伊達 勲編：新 NS NOW 13 脳室を征 服するーアプローチとテクニックの王道. 東京，メジカ ルビュー社, 2018, pp.148-153. 


\section{Editorial Comment}

\section{手術スケッチを描くことで手術の理解を深める}

本論文に述べられているように, 電子カルテの導 入によって, 手術記録にもデジタル化の波が押し寄 せている．また，最近の手術技術の向上によって， 無血の術野が得られることが多くなり, 動画でもか なりのことが理解できるようになった。このため術 後のカンファレンスや研究会でも主に動画のプレゼ ンテーションが求められ, 手術スケッチを描く機会 はますます減少している.

しかし本論文の Fig. 4 に示されているように手術 中のひとつひとつの視野は狭く, 動画の場合にはそ れぞれの部位が別々に示されてしまう。一方，手術 スケッチではこれらをつなぎ合わせて俯瞰的に示す ことが可能で，それを繰り返すことで手術の理解が より深まることは確実である。また脳動脈瘤クリッ ピング術などにおいては, 術者は血管や脳など術野 に見えているものの裏側を意識して操作を行わなく てはならない.さもないと牽引などによって穿通枝
兵庫医科大学脳神経外科 吉村紳一

や脳神経などを傷つけてしまう可能性がある。この ため術者は吸引管や鑷子を用いて，血管などの構造 物の裏側を瞀き, それを脳裏に焼き付けて手術を進 めることになる、つまり, 経験豊富な術者はあたか も「透視」のようなイメージをもちながら手術をし ており，このようなスキルを身につけるには手術ス ケッチを描くことがきわめて有用である。

本論文の考察には「一人の脳神経外科医が経験で きる手術症例は限りがある。そのため 1 つの手術か ら多くを学ぶ姿勢が大切であり, 手術手技の習得に は微小解剖の知識に加え, 手術スケッチは欠かせな い」と述べられている，血管内治療などの低侵襲手 術の普及によって外科手術の機会はさらに減少して いくと考えられ，このような心構えがさらに重要と なってくるだろう。素晴らしい論文をご投稿いただ いた田中俊英先生に感謝申し上げたい. 